UNIO - EU Law Journal. Vol. 4, No. 2, July 2018, pp 18-32.

®2018 Centre of Studies in European Union Law

School of Law - University of Minho
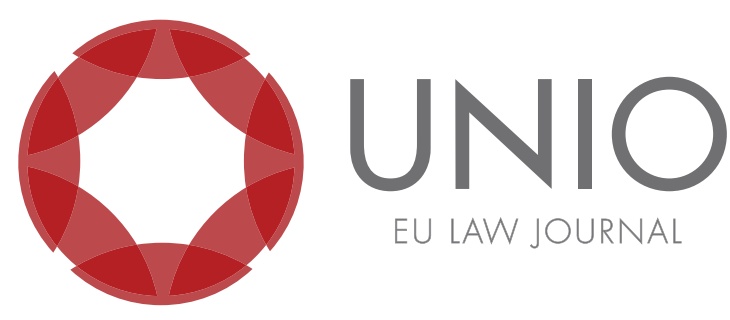

EU LAW JOURNAL

\title{
Digital Single Market and coordination of social security systems - interoperability solutions at the service of social protection
}

Sophie Perez Fernandes*

ABSTRACT: One of the fundamental pillars to the full achievement of the Digital Single Market is the development of eGovernment/e-administration. As a key priority of the current moment of the European integration process, the implementation of the Digital Single Market has the potential to lay down the foundations for a public administration capable of providing crossborder mobility in the Single Market of the Union by means of high quality, interoperable and digital public services. To exemplify the characteristics outlined for the configuration of a public administration of the Digital Single Market, we will seek to give concrete form to the model that is emerging in a specific area of EU law which has critical importance for the European integration process - the coordination of social security systems. Its consideration allows us to test the implementation of the Digital Single Market in the public sector through digital, interoperable, and high-quality cross-border public administration.

KEYWORDS: Digital Single Market - e-administration - interoperability - coordination of social security systems - EESSI system.

\footnotetext{
*Professor at the School of Law of the University of Minho. Team member of the Jean Monnet Project "INTEROP - EU Digital Single Market as a political calling: interoperability as the way forward" funded by EACEA (Education, Culture and Audiovisual Executive Agency).
} 


\section{Digital Single Market and digital, interoperable and high- quality cross-border public administration}

Considered as a key priority on the European political agenda ${ }^{1}$, the Digital Single Market is defined as "one in which the free movement of goods, persons, services and capital is ensured and where individuals and businesses can seamlessly access and exercise online activities under conditions of fair competition, and a high level of consumer and personal data protection, irrespective of their nationality or place of residence." The implementation of the Digital Single Market is based on key interdependent actions in various fields, taken and coordinated at EU level, in particular, in the exercise of its shared competences with the Member States in the field of the Internal Market. ${ }^{4}$ The approach is to embrace the use of information and communication technologies, not as a sector policy, but as a policy to be implemented horizontally, covering all sectors of the economy and of the public sector. Overall, the strategic objective pursued is to enable both citizens and businesses, as well as public services, to take advantage of the opportunities offered by the digitization of the economy and society ${ }^{5}$, ultimately with a view to creating an inclusive digital society that benefits from the digital age. As the Digital Single Market Strategy concludes, the realization of the Digital Single Market "is about transforming European society and ensuring that it can face the future with confidence."

One of the fundamental pillars to the full achievement of the Digital Single Market is the development of e-administration/eGovernment. ${ }^{7}$ As outlined by the European Commission, "[the] public sector, which accounts for over a quarter of total employment and contributes to approximately a fifth of the EU's GDP through public procurement, plays a key role in the digital single market as a regulator, services provider and employer." "With the overall objective of maximizing the sustainable socio-economic benefits of a Digital Single

${ }^{1}$ The idea was reiterated in the commitment made by the legislative triumvirate of the Union to finalize the regulation necessary to achieve the Digital Single Market by the end of 2017 - see Joint Declaration of the Presidents of the European Parliament, the Council and the European Commission on the EU's legislative priorities for 2017, "A Europe that protects, empowers and defends", 13 December 2016 [available at https://ec.europa.eu/commission/sites/beta-political/files/joint-declarationlegislative-priorities-2017-jan2017_en.pdf (last accessed 21.12.2017)].

${ }^{2}$ See Article 26 TFEU.

${ }^{3}$ European Commission, Communication to the European Parliament, the Council, the European Economic and Social Committee and the Committee of the Regions, "A Digital Single Market Strategy for Europe", Brussels, 6.5.2015, COM(2015) 192 final, 3.

${ }^{4}$ See Article 4(2)(a) TFEU.

${ }^{5}$ A 2017 Eurobarometer survey shows that two-thirds of Europeans believe that the most recent digital technologies have a positive impact on society, the economy and their own lives, and most respondents consider that the EU, Member States' authorities and companies need to take action to address the issues raised around digitisation - see European Commission, Communication to the European Parliament, the Council, the European Economic and Social Committee and the Committee of the Regions, on the Mid-Term Review on the implementation of the Digital Single Market Strategy, “A Connected Digital Single Market for All”, Brussels, 10.5.2017, COM(2017) 228 final, 2, referring to the Eurobarometer Survey "Citizens' Attitudes Towards the Impact of Digitisation and Automation on Our Daily Lives", March 2017, not yet published.

${ }^{6}$ European Commission, Communication “A Digital Single Market Strategy for Europe...”, 22.

${ }^{7}$ In this sense, see European Commission, Communication to the European Parliament, the Council, the European Economic and Social Committee and the Committee of the Regions, "EU eGovernment Action Plan 2016-2020 - Accelerating the digital transformation of government”, Brussels, 19.4.2016, COM (2016) 179 final, 1.

${ }^{8}$ European Commission, Communication to the European Parliament, the Council, the European Economic and Social Committee and the Committee of the Regions, "European Interoperability Framework - Implementation Strategy”, Brussels, 23.3.2017, COM(2017) 134 final, 1. 
Market, the Digital Agenda for Europe, one of the flagship initiatives under the Europe 2020 Strategy ${ }^{9}$, had already inscribed support of seamless cross-border eGovernment services in the Single Market amongst its key actions with a view to taking advantage of the benefits of information and communication technologies in the public sector and beyond national borders..$^{10}$ So far, three eGovernment action plans have been consecutively adopted, the first covering the period 2006-2010 ${ }^{11}$, the second adopted following the European Digital Agenda for the period 2011-2015 ${ }^{12}$, and the third action plan for the period 2016-2020, which accompanies the Digital Single Market Strategy. ${ }^{13}$ The balance made in this third action plan of its two predecessors in supporting coordination and collaboration between Member States and the Commission in the conduct of joint actions on eGovernment is overall positive, albeit not fully achieved, as it is recognised that "citizens and businesses are not yet getting the full benefit from digital services that should be available seamlessly across the EU."14

Under the third action plan currently under way, the path outlined to accelerate the digital transformation of government/public administration is guided by the following long-term shared vision: "By 2020, public administrations and public institutions in the European Union should be open, efficient and inclusive, providing borderless, personalised, user-friendly, end-to-end digital public services to all citizens and businesses in the EU. Innovative approaches are used to design and deliver better services in line with the needs and demands of citizens and businesses. Public administrations use the opportunities offered by the new digital environment to facilitate their interactions with stakeholders and with each other." "15 The strategic priorities set out therein seek to lay the foundations for a public administration capable of providing cross-border mobility in the Single Market of the Union by means of high quality, interoperable and digital public services ${ }^{16}$. The abovementioned action plan also sets out a number of principles that forthcoming initiatives should observe in order to "deliver the significant benefits that eGovernment can bring to businesses, citizens and public administrations themselves." 17

Firstly, the initiatives to be launched under the third eGovernment action plan

\footnotetext{
${ }^{9}$ European Commission, Communication "EUROPE 2020 - A strategy for smart, sustainable and inclusive growth", Brussels, 3.3.2010, COM(2010) 2020 final, 14; and Communication to the European Parliament, the Council, the European Economic and Social Committee and the Committee of the Regions, "A Digital Agenda for Europe”, Brussels, 19.5.2010, COM(2010)245 final.

${ }^{10}$ See European Commission, Communication "A Digital Agenda for Europe...", 36-38.

${ }^{11}$ See European Commission, Communication to the European Parliament, the Council, the European Economic and Social Committee and the Committee of the Regions, "i2010 eGovernment Action Plan: Accelerating eGovernment in Europe for the Benefit of All”, Brussels, 25.4.2006, COM (2006) 173 final.

${ }^{12}$ See European Commission, Communication to the European Parliament, the Council, the European Economic and Social Committee and the Committee of the Regions, "The European eGovernment Action Plan 2011-2015 - Harnessing ICT to promote smart, sustainable \& innovative Government", Brussels, 15.12.2010, COM (2010) 743 final.

13 See European Commission, Communication to the European Parliament, the Council, the European Economic and Social Committee and the Committee of the Regions, "EU eGovernment Action Plan 2016-2020 - Accelerating the digital transformation of government”, Brussels, 19.4.2016, COM (2016) 179 final.

${ }^{14}$ See European Commission, Communication "EU eGovernment Action Plan 2016-2020 - Accelerating the digital transformation of government...", 2 .

${ }^{15}$ Ibidem, 3.

${ }^{16}$ Ibidem, 4-12.

${ }^{17}$ Ibidem, 2.
} 
should observe three "by default" principles: the principle digital by default ${ }^{8}$, the principle cross-border by default and the principle interoperability by default. Interoperability is a key factor for the implementation and effectiveness of a digital public administration operating on a cross-border scale and, thus, for the implementation of the Digital Single Market ${ }^{19}$, as it ensures, in a cross-sectoral approach, that cross-border connections are not only between public administrations, but also between public administrations and citizens and businesses.

In addition to these principles "by default", the initiatives to be launched under the third eGovernment action plan should also observe the once only principle. The scope of this principle is not limited to allowing a single contact to be sufficient for the transmission of information, the submission of applications/requests or the submission of documents to the public administration of a given Member State, burdening the latter with its re-use and possible retransmission to the competent authorities, respecting the rules applicable to data protection. In so far as the public administration of the Digital Single Market is, as previously mentioned, cross-border and interoperable by default, the Digital Single Market Strategy provides for the extension of this principle across borders. ${ }^{20}$

Last, but far from being the least important, the document under analysis adds the principles of inclusiveness and accessibility, openness and transparency, and trustworthiness and security, all of which have the aim of creating a climate of trust in the adoption and use of digital public services. ${ }^{21}$ The strategic priorities of this third eGovernment action plan seek to facilitate and promote cross-border mobility of citizens and businesses, which implies the exercise of the rights conferred on them by EU law, by means of public services which are not only digital and interoperable but also of high quality in order to "contribute to engaging citizens, businesses and civil society in the collaborative design, production and delivery of public services and to facilitate interaction between public administrations and businesses and citizens. ${ }^{, 22}$

As the Digital Single Market is also a space of exercise of public power within the Union, its implementation via digital and interoperable public services on a

\footnotetext{
${ }^{18}$ Announced in the Digital Single Market Strategy (see European Commission, Communication "A Digital Single Market Strategy for Europe", 16-17) and again in the third eGovernment action plan [see European Commission, Communication "EU eGovernment Action Plan 2016-2020 - Accelerating the digital transformation of government", 8-9], the European Commission submitted its proposal for a Single Digital Gateway in 2017 - see European Commission, Proposal for a Regulation of the European Parliament and of the Council on establishing a single digital gateway to provide information, procedures, assistance and problem solving services and amending Regulation (EU) No 1024/2012, Brussels, 2.5.2017, COM(2017) 256 final.

19 See European Commission, Communication "European Interoperability Framework - Implementation Strategy...”, 2. For the period 2016-2020 the ISA 2 Programme promotes interoperability solutions and common frameworks for European public administrations, businesses and citizens - see Decision (EU) 2015/2240 of the European Parliament and of the Council of 25 November 2015 establishing a programme on interoperability solutions and common frameworks for European public administrations, businesses and citizens (ISA ${ }^{2}$ programme) as a means for modernising the public sector, OJ L 318, 4.12.2015, p. 1-16.

${ }^{20}$ See European Commission, Communication "A Digital Single Market Strategy for Europe...”, 16. The Commission committed itself to assess the possibility of applying the once-only principle for citizens in a cross-border context by 2019 - see European Commission, Communication "European Interoperability Framework - Implementation Strategy...”, 11.

${ }^{21}$ European Commission, Communication "EU eGovernment Action Plan 2016-2020 - Accelerating the digital transformation of government...", 4.

${ }^{22}$ Ibidem, 12.
} 
cross-border operational scale could not bypass a previous commitment to improve the quality of the exercise of power at EU level ${ }^{23}$ based, among others, on standards of good administration aimed at creating/inspiring a climate of trust in the exercise of public power within the EU. ${ }^{24}$ Such standards of good administration are also to be conceived in light of the digital age (digital good administration), particularly in articulation with the (fundamental) right to protection of personal data. ${ }^{25}$ This explains why an approach focused on the citizen of the digital age - the citizen-userruns through the document under analysis.

Given the administrative paradigm that characterised the genesis of the European integration process ${ }^{26}$, it is not surprising that the digital burden primarily impacts on public administrations ${ }^{27}$, especially on the public administrations of the Member States. The European Commission is not, of course, silent about "its own digital transformation". ${ }^{28}$ As a result, it is the administrative authority of the EU as a whole ${ }^{29}$ which is called to digitally transformed ensure the implementation of the Digital Single Market as a key priority of the current moment of the European integration process. However, given their protagonist role as EU Administrations of general jurisdiction ${ }^{30}$, entrusted with the implementation of EU law as a mission "which is essential for the proper functioning of the Union" and "regarded as a matter of common interest ${ }^{\prime 31}$, the public administrations of the Member States are the first to be targeted by this "digital transformation" which is intended to be "accelerated". Thus, the proper functioning and the success of the Digital Single Market will primarily

\footnotetext{
${ }^{23}$ See European Commission, "European Governance - A White Paper", Brussels, 25.7.2001, $\operatorname{COM}(2001) 428$ final, 5.

${ }^{24}$ Including the principle of good administration, together with the principles of transparency, equality of arms and precaution, amongst the "trust-enhancing principles" arising from the case-law of the ECJ in order to "strengthen the accountability of the Union and the Member States to the citizens", see Koen Lenaerts, “In the Union we trust': trust-enhancing principles of Community law”, Common Market Law Review 41 (2004), 336-340.

${ }^{25}$ See Catarina Sarmento e Castro, "Artigo 8. - Proteção de dados pessoais", in Carta dos Direitos Fundamentais da União Europeia Comentada, coord. Alessandra Silveira and Mariana Canotilho (Coimbra: Almedina, 2013), 120-128.

${ }^{26}$ On the subject, see Sophie Perez Fernandes, "Administração Pública", in Direito da União Europeia - Elementos de Direito e Politicas da União, coord. Alessandra Silveira, Mariana Canotilho and Pedro Madeira Froufe (Coimbra: Almedina, 2016), 74-77.

${ }^{27}$ This was one of the conclusions of the \#Digital4EU Stakeholder Forum organised by the European Commission with the objective of analysing the progress made in creating the Digital Single Market - see European Commission, \#Digital4EU 2016 Report, Brussels, 25.2.2016 [available at https:// ec.europa.eu/digital-single-market/en/news/digital4eu-2016-report (last accessed 21.12.2017)].

${ }^{28}$ See European Commission, Communication "EU eGovernment Action Plan 2016-2020 - Accelerating the digital transformation of government...", 5 .

${ }^{29}$ See Jacques Ziller, "L'autorité administrative dans l'Union européenne", in L'autorité de l'Union européenne, dir. Loïc Azoulai and Laurence Burgorgue-Larsen (Brussels: Bruylant, 2006), 122.

${ }^{30}$ Taking advantage of the expression used by the (then) Court of First Instance referring, however, to the national courts - see Judgment of the General Court, Tetra Pak, 10 July 1990, Case T-51/89, EU:T:1990:41, recital 42. Also qualifying the national public administrations as "administrations communes du système européen", see Mario Chiti, "Les droits administratifs nationaux entre harmonisation et pluralisme eurocompatible", in Traité de droit administratif européen, $2^{\text {nd }}$ edition, dir. Jean-Bernard Auby and Jacqueline Dutheil de la Rochère (Brussels: Bruylant, 2015), 870.

31 See Articles 291 and 197 TFEU, respectively. On the importance of these provisions in their post-Lisbon Treaty wording for the structuring of EU's composite or multilevel, but integrated, administrative system, see Jürgen Schwarze, "European Administrative Law in the Light of the Treaty of Lisbon”, European Public Law 18(2) (2012), 285-304; and Mario Chiti, Les droits administratifs nationaux entre harmonisation et pluralisme eurocompatible..., 874-875.
} 
depend on the commitment of the public administrations of the Member States in implementing this matter of common interest.

\section{Digital Single Market at the service of the coordination of social security systems}

To exemplify the characteristics outlined for the configuration of a public administration of the Digital Single Market, we will seek to give concrete form to the model that is emerging in a specific area of EU law and of capital importance for the European integration process - the coordination of social security systems.

This social dimension of the European integration process, present since its first hour, could not escape the creation of the Digital Single Market. This is so because the coordination of social security systems is aimed at guaranteeing free movement of persons as a right enshrined in the genetic code of the European integration process ${ }^{32}$, free movement which, as previously seen, is the key component for understanding the very concept of Digital Single Market ${ }^{33}$ and, thus, its implementation through digital, interoperable, cross-border public administration. ${ }^{34}$ The essential nature of this link between freedom of movement of persons and coordination of social security systems is part of the acquis communnautaire built under the regulations which have consecutively been adopted in the latter matter, which did not apply, and still do not apply, in situations confined to a single Member State. The aim is to prevent the particular features of national social security systems from hindering the freedom of movement of persons, in the sense of making it less attractive.

It is intuitive to understand that the exercise of the right to move and reside freely within the territory of the Member States would be less attractive if the social security rights of those who effectively exercise it, moving from one Member State to another, whether accompanied by their families or not, were not protected. This is so because, under the principle of territoriality, national social security legislations would not be capable on their own of responding to, or of responding adequately to the corresponding (cross-border) situations. ${ }^{35}$ It would, therefore, be possible for the same situation to fall within the scope of application of the legislation of more than one Member State, or even none, with the consequent loss of social security rights or benefits acquired or in the process of being acquired unaccompanied by the constitution of new rights or the granting of new benefits.

The relevance of the mobility of individuals in the field of social security has, moreover, a historical record ${ }^{36}$, especially in the European context. Indeed,

\footnotetext{
32 Apart from fundamental economic freedom, which is embedded in the professional freedoms guaranteed by the Treaties as pillars of the internal market (freedom of movement for workers, freedom of establishment and freedom to provide services - Articles 45, 49 and 56 TFEU), the free movement and residence of nationals of the Member States forms part of the essential core of their status as EU citizens [Articles 20(2)(a) and 21 TFEU], as wells as being recognised as a fundamental right [Articles 15(2) and 45 CFREU].

${ }^{33}$ See European Commission, Communication "A Digital Single Market Strategy for Europe...", 3.

${ }^{34}$ See European Commission, Communication "EU eGovernment Action Plan 2016-2020 - Accelerating the digital transformation of government...", 3 .

35 On the impact of the coordination of social security systems in the Union on the principle of territoriality, see Rob Cornelissen, "Achievements of 50 years of European social security coordination", in 50 years of Social Security Coordination Past - Present - Future, Report of the conference celebrating the $50^{\text {th }}$ Anniversary of the European Coordination of Social Security, ed. Yves Jorens (European Commission, EU, 2010), 56-57.

${ }^{36}$ See Simon Roberts, "A short history of social security coordination", in 50 years of Social Security
} 
Regulations Nos 3/58 and 4/58 are, respectively, the third and fourth regulations adopted under the Treaty of Rome (1957) and the first relating to non-institutional matters. ${ }^{37}$ It was, however, under Regulation No 1408/71, accompanied by Regulation No $574 / 72^{38}$, that the coordination of social security systems in the EU has been solidifying, but also complexifying. During this long period the regime has been subject to numerous amendments and updates, dictated by the need to adjust its normative content to changes in legislation at national level or to developments resulting from jurisprudence of the European Court of Justice (ECJ), contributing to the complexity of the coordination rules, and calling for a revision. Since 1 May 2010 ${ }^{39}$, Regulation No 883/2004 (basic Regulation), together with Regulation No 987/2009 (implementing Regulation) ${ }^{40}$, have institutionalized a modernized system of social security coordination ${ }^{41}$, which, drawing on the experience gained under the previous schemes, seeks to simplify EU rules in this area and to promote the protection of the rights of the persons covered. ${ }^{42}$

The EU's approach in social matters is based on a logic of coordination, not only of coordination of Member States' social policies based on an Open Method of Coordination $^{43}$ (allowing Member States to define their own social policies in view of

Coordination Past - Present - Future, Report of the conference celebrating the $50^{\text {th }}$ Anniversary of the European Coordination of Social Security, ed. Yves Jorens (European Commission, EU, 2010), 8-28. ${ }^{37}$ See Regulation No 3 of the Council of 25 September 1958 concerning social security for migrant workers, OJ No 30, 16.12.1958, p. 561-596; and Regulation No 4 of the Council of 3 December 1958 laying down implementing procedures and supplementing the provisions of Regulation No 3 concerning social security for migrant workers, OJ No 30, 16.12.1958, p. 597-664.

${ }^{38}$ See Regulation (EEC) No 1408/71 of the Council of 14 June 1971 on the application of social security schemes to employed persons and their families moving within the Community, OJ L 149, 5.7.1971, p. 2-50; and Regulation (EEC) No 574/72 of the Council of 21 March 1972 fixing the procedure for implementing Regulation (EEC) No 1408/71 on the application of social security schemes to employed persons and their families moving within the Community, OJ L 74, 27.3.1972, p. $1-83$.

39 Though adopted in 2004, Regulation 883/2004 only applied, by virtue of its Article 91, since May 1, 2010, date of entry into force of the implementing Regulation (see Article 97 of Regulation $987 / 2010)$

${ }^{40}$ See Regulation (EC) No 883/2004 of the European Parliament and of the Council of 29 April 2004 on the coordination of social security systems, OJ L 166, 30.4.2004, p. 1-123; and Regulation (EC) No 987/2009 of the European Parliament and of the Council of 16 September 2009 laying down the procedure for implementing Regulation (EC) No 883/2004 on the coordination of social security systems, OJ L 284, 30.10.2009, p. 1-42.

${ }^{41}$ See Article 153(1)(k) TFEU.

${ }^{42}$ Those two regulations have already been amended - see, most recently, Commission Regulation (EU) No 1372/2013 of 19 December 2013 amending Regulation (EC) No 883/2004 of the European Parliament and of the Council on the coordination of social security systems and Regulation (EC) No 987/2009 of the European Parliament and of the Council laying down the procedure for implementing Regulation (EC) No 883/2004, OJ L 346, 20.12.2013, p. 27-28; also, with relevance, see Regulation (EU) No 1231/2010 of the European Parliament and of the Council of 24 November 2010 extending Regulation (EC) No 883/2004 and Regulation (EC) No 987/2009 to nationals of third countries who are not already covered by these Regulations solely on the ground of their nationality, OJ L 344, 29.12.2010, p. 1-3. A further amendment is under discussion - see European Commission, Proposal for a Regulation of the European Parliament and of the Council amending Regulation (EC) No $883 / 2004$ on the coordination of social security systems and Regulation (EC) No 987/2009 laying down the procedure for implementing Regulation (EC) No 883/2004, 13.12.2016, COM(2016) 815 final. The proposal focuses on four areas of coordination where improvements are required: economically inactive citizens' access to social benefits, long-term care benefits, unemployment benefits and family benefits.

43 The Open Method of Coordination presented under the so-called Lisbon Strategy, is an 
the achievement of objectives defined at EU level), but also of coordination of the social security systems of the Member States, which ensures that the competences of the Member States to define their social security systems is preserved ${ }^{44}$ while $^{2}$ ensuring the continuity of social protection for persons across Member States. In other words, the EU's social security regulation does not seek either to harmonize national social security systems nor to replace them by a single scheme common to the Member States. This does not mean that the rules set out bypass the inevitable differences between the social security systems defined by the Member States. They rather, seek to accommodate those differences in order to, with "respect [to] the special characteristics of national social security legislation", "guarantee within the [Union] equality of treatment under the different national legislation for the persons concerned" and "that persons moving within the [Union] (...) retain the rights and the advantages acquired and in the course of being acquired."45

Thus, from the moment that the digital age arrives at the Internal Market of the Union, with the aim of deepening the European integration process, the coordination of social security systems as an essential vector of the integration process could not go unscathed. Furthermore, since closer and more effective cooperation between social security (administrative) authorities and institutions ${ }^{46}$ is expressly regarded as a "key factor" ${ }^{\text {"47 }}$ for the coordination of social security systems, its consideration allows us to test the implementation of the Digital Single Market in the public sector. To this end, we will seek in the following analysis to decipher, in the currently in force Regulations that institutionalize in the EU a modernized system of social security coordination, the characteristics identified above regarding the configuration of a public administration of the Digital Single Market.

(i) Firstly, under the modernized system of social security coordination, the authorities and institutions of the Member States act, by default, on a cross-border operational scale. This is so because the Regulations in force only apply to persons "who are or have been subject to the legislation of one or more Member States". ${ }^{48}$ In dealing with such cross-border cases, social security institutions ${ }^{49}$ often need to communicate

intergovernmental method of policy-making in fields within the competence of the Member States (such as social protection), a method which seeks to achieve greater convergence of such policies towards mains goals defined at EU level - see European Council, Lisbon European Council 23 and 24 March 2000, Presidency Conclusions, para. 37 [available at http:/ /www.europarl.europa.eu/summits / lis1_en.htm (last accessed 21.12.2017)]. The same logic underlies the European Pillar of Social Rights see European Commission, Communication to the European Parliament, the Council, the European Economic and Social Committee and the Committee of the Regions, "Establishing a European Pillar of Social Rights", Brussels, 26.4.2017, COM(2017) 250 final; and the Commission Staff Working Document accompanying the Communication "Establishing a European Pillar of Social Rights", Brussels, 26.4.2017, SWD(2017) 206 final.

${ }^{44}$ See Article 153(4) TFEU.

${ }^{45}$ See recitals 4, 5 and 13 of Regulation 883/2004.

${ }^{46}$ To a certain extent, the terminology used is rather neutral, oscillating between "institution" and "authority". According to Article 1(p) of Regulation 883/2004, "institution" refers to the body or authority responsible, in respect of each Member State, for applying all or part of the legislation relating to the social security branches covered by Article 3(1) of Regulation 883/2004. In turn, "competent authority" refers to the Minister(s) or other equivalent authority responsible for social security schemes throughout or in any part of the Member State in question (see Article 1(m) of Regulation 883/2004).

${ }^{47}$ See recital 2 of Regulation 987/2010.

${ }^{48}$ See Article 2(1) of Regulation 883/2004.

${ }^{49}$ It should be noted that the modernized system of social security coordination applies not only to 
and exchange information between themselves. This is the case, primarily, for the purpose of determining the legislation applicable. According to the principle of single applicable law, persons to whom the coordination regime applies shall be subject to the legislation of a single Member State only ${ }^{50}$, such legislation being determined in accordance with the rules laid down in the basic Regulation and supplemented in the implementing Regulation. ${ }^{51}$

According to settled case-law of the ECJ, those provisions constitute "a complete and uniform system of conflict rules, the aim of which is to ensure that workers moving within the Union are subject to the social security scheme of only one Member State, in order to prevent the national legislation of more than one Member State from being applicable and to avoid the attendant complications of such a situation. ${ }^{152}$ Apart from the complexity of such a system made up of general, special and exceptional rules, it is easy to see that the determination of the specific legislation applicable, with all the consequences that this entails in terms of rights and obligations, depends on the assessment of the objective situation of the person concerned, as well as (where appropriate) their relatives, by the institutions of more than one Member State. Therefore, under the general obligation set forth in Article 2(2) of the implementing Regulation, the institutions of the Member States concerned "shall without delay provide or exchange all data necessary for establishing and determining the rights and obligations of persons to whom the basic Regulation applies. 53

(ii) To this end, the modernized system of social security coordination in force since 2010 has chosen electronic communications as "a suitable means of rapid and reliable data exchange between Member States' institutions. ${ }^{54}$ Specifically, Article 78 of the basic Regulation calls on the Member States to "progressively use new technologies for the exchange, access and processing of the data required" to its application. In turn, Article 4 of the implementing Regulation imposes electronic means for the transmission of data between institutions, as well as a privileged option for their communications with the persons concerned. As previously mentioned, the paradigm of a public administration digital by default adds that of a public administration interoperable by default. In this regard, in its third eGovernment action plan, the European Commission had announced the creation of the EESSI system - Electronic Exchange of Social Security Information. ${ }^{55}$

The central EESSI system was made available by the Commission in July $2017^{56}$ and its implementation is expected to be completed in $2019^{57}$, leaving the

the Member States of the EU, but also to Iceland, Liechtenstein and Norway under the Agreement on the European Economic Area and to Switzerland under the EC/Switzerland Agreement.

${ }^{50}$ See Article 11(1) of Regulation 883/2004.

${ }^{51}$ See Articles 11 to 16 of Regulation 883/2004 and Articles 14 to 21 of Regulation 937/2009.

${ }^{52}$ See, most recently, judgments of the Court in X, C-569/15, EU:C:2017:673, para. 15; and in $X$, C-570/15, EU:C:2017:674, para. 14.

${ }^{53}$ See also Article 20 of Regulation 987/2009. In order to ensure the protection of the person while the necessary exchanges take place between the institutions of the Member States concerned, Article 6 of Regulation 987/2009 provides for the provisional application of the social security legislation and the provisional granting of benefits.

${ }^{54}$ Recital 3 of Regulation 987/2009.

${ }^{55}$ See European Commission, Communication 'EU eGovernment Action Plan 2016-2020 - Accelerating the digital transformation of government...", 10.

${ }^{56}$ See http://ec.europa.eu/ social/ main.jsp?langId=en\&catId=849\&newsId=2836\&furtherNews=yes (last accessed 21.12.2017).

${ }^{57}$ See European Commission, Communication "EU eGovernment Action Plan 2016-2020 - Accelerating the digital transformation of government...", 11. 
Member States with a 2-year period to ensure the interconnection of their social security institutions with the central EESSI system. Through structured electronic documents and following commonly agreed procedures, the aim of this system is to facilitate, speed up and simplify the secure exchange of data between the social security institutions of the Member States by ensuring access to complete and accurate information in the handling of individual cases, thereby helping institutions to combat fraud and error, in addition to contributing to faster procedures for the persons concerned, ensuring faster and more efficient calculation and payment of their benefits.

(iii) In any case, and for the purposes mentioned, this electronic system must operate in a common secure framework capable of guaranteeing the protection of the personal data that is thereby exchanged. Therefore, the regulations that institutionalize the modernized system of social security coordination do not bypass the respect for standards of digital good administration, with emphasis for protection of personal data. Accordingly, when collecting, transmitting, or processing personal data between different authorities or institutions under the rules of the modernized system of social security coordination, Member States shall ensure that the persons concerned are able to exercise fully their rights regarding personal data protection in accordance with EU provisions on the protection of personal data. ${ }^{58}$

This does not mean that other (general) standards of good administration are not covered by the modernized system of social security coordination. On the contrary, the regulations also take care of the ad extra relational scope of administrative action in the field of social security - that is to say, the relations between the social security institutions of the Member States and the persons concerned. Article 76(4) of the basic Regulation subjects both those institutions and the persons covered by its scope of application to a "duty of mutual information and cooperation" to ensure its correct implementation. For the social security institutions of the Member States, this duty to ensure the correct implementation of the modernized system of social security coordination entails in their relations with the persons concerned ${ }^{59}$ the observance of rules that meet EU standards of good administration. Indeed, not only does the basic Regulation provide for an express reference to the principle of good administration ${ }^{60}$, but also both Regulations include some rules which mirror the rights enshrined in Article 41 CFREU under the "right to good administration".

In general terms, Article 2(1) of the implementing Regulation lists the principles on which "exchanges between Member States' authorities and institutions and persons covered by

\footnotetext{
${ }^{58}$ See Article 77 of Regulation 883/2004 and Article 3(3) of Regulation 937/2009.

${ }^{59}$ As mentioned in the text, under Article 76(4) of Regulation 883/2004 the duty of information and cooperation is mutual which implies that there are some obligations of information and cooperation incumbent on the persons to whom it applies in relation to the social security institutions of the Member States. Accordingly, persons covered by the scope of application of Regulation 883/2004 are required to forward to the relevant institution the information, documents or supporting evidence necessary to establish their situation or that of their families, to establish or maintain their rights and obligations and to determine the applicable legislation and their obligations under it (see Article 3(2) of Regulation 937/2009). They are also required, as soon as possible, to inform the institutions of the competent Member State and of the Member State of residence of any change in their personal or family situation which affects their right to benefits, and failure to respect such obligation of information may result in the application of proportionate measures in accordance with national law and with respect to the principles of equivalence and effectiveness (see Article 76(4) and (5) of Regulation 883/2004).

${ }^{60}$ See Article 76(4) of Regulation 883/2004.
} 
the basic Regulation" shall be based, namely "the principles of public service, efficiency, active assistance, rapid delivery and accessibility, including e-accessibility, in particular, for the disabled and the elderly." In turn, the basic Regulation imposes on the institutions of the Member States, "in accordance with the principle of good administration", (i) to provide the persons concerned with any information required for exercising their rights ${ }^{61}$ and (ii) to respond to all queries without delay and in all cases within any time limits specified under national legislation, which shall be reasonable. ${ }^{62}$ The implementing Regulation further imposes on the institutions of the Member States (iii) the obligation to notify the claimant residing or staying in another Member State of its decision; (iv) the obligation to indicate the reasons for refusal and $(v)$ the remedies and periods allowed for appeals, as well as $(v i)$ the obligation to send a copy of its decisions to other involved institutions. ${ }^{63}$ This listing even goes beyond that enshrined in Article 41 CFREU and, contrary to this provision of EU primary law, its binding nature for the institutions of the Member States applying the modernized system of social security coordination, thus implementing EU law within the meaning of Article 51(1) CFREU, is undeniable.

Confirming this assertion are the solutions given by the modernized system of social security coordination to the linguistic problems that are inherent of a space such as that of the Union where linguistic diversity is not only a fundamental value ${ }^{64}$ but also a "specific expression of the plurality inherent in the European Union". ${ }^{55}$ In the field of social security in particular, the lack of skills in other languages may easily lead to confusions for those moving within the Union and constitute an obstacle to the exercise of rights to benefits or to the fulfilment of obligations under national legislations, the observance of which the system of social security coordination aims to ensure. That is the reason why, under Article 76(7) of the basic Regulation, applications and other documents submitted to authorities, institutions, and tribunals of one Member State may not be rejected on the grounds that they are not written in the official language of that State. Individuals may, where they consider it necessary or desirable, submit applications, letters and certificates in their own language, provided that it is one of the official languages of the EU.6

This solution enables the persons concerned to express themselves so that they can be heard. Also, over time, it is expected that the difficulties that this may cause for the social security institutions of the Member States will eventually be mitigated due to the use of structured electronic documents and procedures within the EESSI system. Without going so far as to impose on those institutions an obligation to respond to the persons concerned in the same language that they chose to interact with them ${ }^{67}$, the principle of good administration would, however, impose on them an obligation to communicate with the persons concerned in a language accessible or easily understood

\footnotetext{
${ }^{61}$ See Article 76(4) of Regulation 883/2004 and Article 3(1) of Regulation 937/2009.

${ }^{62}$ See Article 76(4) of Regulation 883/2004 and Article 3(4) of Regulation 937/2009.

${ }^{63}$ See Article 3(4) of Regulation 937/2009.

${ }^{64}$ See Article 3(3) TEU and Article 22 CFREU.

${ }^{65}$ See Opinion of Advocate General Miguel Poiares Maduro in Eurojust, C-160/03, EU:C:2004/817, para. 35.

${ }^{66}$ See Article 55(1) TEU and Article 1 of Regulation No 1 of 15 April 1958 determining the languages to be used by the European Economic Community, and Article 1 of Regulation No 1 of 15 April 1958 determining the language to be used by the European Atomic Energy Community, OJ 17, 6.10.1958, p. 385-386 and 401-402.

${ }^{67}$ On the other hand, the linguistic choice made by the person concerned at the time when he or she addresses to an institution of the Union or to some of its bodies obliges them to reply in that language - see Article 20(2)(d) TFEU and 41(4) CFREU.
} 
by the average citizen ${ }^{68}$, that is to say, in such a way that the persons concerned may also understand the institution of the Member State in question.

(iv) The importance of these obligations of cooperation and exchange of information is particularly evident when information, documents or requests are mistakenly submitted by the persons concerned to the institution of a Member State which is not competent in accordance with the basic Regulation. Oftentimes, it is difficult for the persons concerned to provide information, submit documents, or make requests within the time limits laid down in the national legislation applicable - firstly because, as was previously mentioned, doubts may arise in determining the specific national legislation applicable.

Failure to address such situations would entail the risk of total or partial loss of rights to benefits which the national legislation applicable provides for and that the modernized system of social security coordination in the Union aims to safeguard. To avoid such undesirable consequences, the basic Regulation ensures that any claim, declaration or appeal shall be admissible if submitted, within the time limit applicable, to a corresponding authority, institution or tribunal of another Member State (such as the Member State of residence). ${ }^{69}$ In turn, the implementing Regulation requires the receiving institution to resubmit/retransmit without delay the information, documents or claims to the competent institution, indicating the date on which they were initially submitted, a date that shall be binding on the latter institution. ${ }^{70}$

It is possible to identify in this solution a special and particularly protective dimension of the once only principle. This principle is intended to exhaust (desirably) in a single contact the needs of interaction between citizens and businesses and public administrations, burdening the latter with the re-use of the data thus transmitted and, if necessary, with its retransmission to the competent authorities. In the field of social security, the modernized system of social security coordination under analysis provides for a solution which obliges the social security institutions of the Member States to recover and share data which has been mistakenly submitted to them by the persons concerned. This obligation of retransmission, therefore, has the purpose of enabling the effective consideration of that information, documents or claims for the purposes of public service (social security) for which they were initially submitted, while avoiding the persons concerned to be exposed (with possible losses) to the administrative complexity which characterizes the field of social security and only increases when considered on a cross-border scale. If this interpretation of the obligation of retransmission under the once only principle is accepted, as both legal solutions aim to avoid a multiplicity of contacts with public services, within the modernized system of social security coordination, it is apparent that the scope of the once only principle already operates on a cross-border scale.

(v) Lastly, as was pointed out above, it is the administrative authority of the EU

\footnotetext{
${ }^{68}$ Echoing the proposal made in relation to the EU level of exercise of public power by Miriam Aziz, "Mainstreaming the Duty of Clarity and Transparency as part of Good Administrative Practice in the EU”, European Law Journal 10(3) (2004), 282-295.

${ }^{69}$ See Article 81 of Regulation 883/2004.

${ }^{70}$ See Article 2(3) of Regulation 937/2009.

Although, for these situations, Article 81 of Regulation 883/2004 requires the authority, institution or tribunal receiving the claim, declaration or appeal to "forward it without delay", Article 2(3) of Regulation 937/2009 safeguards Member State institutions from being "held liable, or be deemed to have taken a decision by virtue of their failure to act as a result of the late transmission of information, documents or claims by other Member States' institutions."
} 
as a whole which is called upon to ensure the implementation of the Digital Single Market, that is, not only the administrative authorities of the Member States, but also the institutions, bodies, offices and agencies of the EU. Though the application of the modernized system of social security coordination is primarily in the hands of the administrations of the Member States, it does not mean that the EU, in particular through the European Commission, is not involved. Thus, the latter is represented in the two bodies established by the basic Regulation, comprising of mainly or exclusively government representatives of each of the States to which the modernized system of social security coordination applies (a member and an alternate member): on the one hand, a representative of the European Commission chairs the Advisory Committee for the Coordination of Social Security Systems ${ }^{71}$, and, on the other hand, attends the meetings of the Administrative Commission for the Coordination of Social Security Systems in an advisory capacity. ${ }^{72}$

Given the importance of cooperation between social security institutions and authorities of the Member States for the proper application of the modernized system of social security coordination, the role entrusted to the Administrative Commission for the Coordination of Social Security Systems deserves special attention. According to the basic Regulation, the Administrative Commission shall, inter alia, deal with all administrative questions and questions of interpretation arising from the provisions of both Regulations, promote the exchange of experience and best administrative practices in view of its uniform application, and foster cooperation between Member States in the area of coordination of social security systems, taking into account particular questions or facilitating the realisation of cross-border cooperation activities. ${ }^{73}$

In light of the complexity inherent to the field of social security, which only increases when considered on a cross-border scale, it is intuitive to consider the emergence of difficulties of interpretation or application arising from the coordination system, which may hinder the exercise of rights to benefits that it actually seeks to safeguard. To remedy such difficulties, the modernized system of social security coordination prioritizes cooperation between the institutions of the Member States involved, while ensuring the intervention of the Administrative Commission if

\footnotetext{
${ }^{71}$ See Article 75(1) of Regulation 883/2004. In addition to being chaired by a representative of the European Commission and comprising one government representative from each Member State, the Advisory Committee for the Coordination of Social Security Systems also comprises one representative from the trade unions and one representative from the employers' organisations from each Member State. The Advisory Committee is empowered to examine general questions and problems arising from the implementation of the EU provisions on the coordination of social security systems, and to formulate opinions on such matters for the Administrative Commission and proposals for any revisions of the said provisions. The Advisory Committee exercises such powers on its own initiative or at the request of the Administrative Commission for the Coordination of Social Security Systems or of the European Commission - see Article 75 of Regulation 883/2004.

${ }^{72}$ See Article 71(1) of Regulation 883/2004. Under Article 71(3) of Regulation 883/2004 the secretarial services for the Administrative Commission is also provided by the European Commission. The Administrative Commission for the Coordination of Social Security Systems comprises one government representative from each of the Member States and is chaired by the member belonging to the State whose representative to the Council of the European Union holds, for the same period, the office of President of the Council of the European Union in accordance with Article 16(9) TEU and Article 236(b) TFEU - see Article 3(1) of the Rules of the Administrative Commission for the Coordination of Social Security Systems attached to the European Commission of 16 June 2010, OJ C 213, 6.8.2010, p. 20-25.

${ }^{73}$ See Article 72 of Regulation 883/2004.
} 
a solution cannot be found. ${ }^{74}$ Conciliation procedures have, therefore, been laid down to be followed, for example, in case of doubts concerning the validity of a document or the accuracy of the facts stating the position of a person contained in a document issued by the institution of a Member State ${ }^{75}$ and in case of difference of views between Member States in determining the applicable legislation. ${ }^{76}$ To this end, the Administrative Commission for the Coordination of Social Security Systems has specified the standard procedure to be followed before the matter may be referred to it, in addition to defining more clearly its role in conciliation procedures. ${ }^{77}$

The Administrative Commission for the Coordination of Social Security Systems also does not escape the digital age in the fulfilment of its missions. The basic Regulation specifies that the Administrative Commission shall "encourage as far as possible the use of new technologies in order to facilitate the free movement of persons". ${ }^{78}$ Also, the Administrative Commission shall ensure that the information needed for the parties concerned to be aware of their rights and the administrative formalities required are, where possible, disseminated electronically via publication online on sites accessible to the public, as well as to ensure that the information is regularly updated. ${ }^{79}$ It is also for the Administrative Commission to lay down the structure, content, format, and detailed arrangements for exchange of documents and structured electronic documents and the practical arrangements for sending information, documents, or decisions by electronic means to the persons concerned. ${ }^{80}$ In organic terms, to speed up the adoption of common rules for the development and use of data-processing services for the exchange of information under the coordination system, a Technical Commission for Data Processing was attached to the Administrative Commission. ${ }^{81}$ The role of the Administrative Commission for the Coordination of Social Security Systems is of paramount importance until the EESSI system becomes fully operational, since it is for the Administrative Commission to lay down the practical arrangements to ensure the necessary data exchange under both Regulations during the current transitional period..$^{82}$

\footnotetext{
${ }^{74}$ See Article 76(6) of Regulation 883/2004.

${ }^{75}$ See Article 5 of Regulation 937/2009.

${ }^{76}$ See Article 6 of Regulation 937/2009.

${ }^{77}$ See Decision No A1 of 12 June 2009 concerning the establishment of a dialogue and conciliation procedure concerning the validity of documents, the determination of the applicable legislation and the provision of benefits under Regulation (EC) No 883/2004 of the European Parliament and of the Council, OJ C 106, 24.4.2010, p. 1-4.

${ }^{78}$ See Article 72(d) of Regulation 883/2004.

${ }^{79}$ See Article 89 of Regulation 987/2009.

${ }^{80}$ See Article 4 of Regulation 987/2009.

${ }^{81}$ See Article 73 of Regulation 883/2004 and Decision No H8 of 17 December 2015 (updated with minor technical clarifications on 9 March 2016) concerning the methods of operation and the composition of the Technical Commission for Data Processing of the Administrative Commission for the Coordination of Social Security Systems, OJ C 263, 20.7.2016, p. 3-6.

${ }^{82}$ See Article 95 of Regulation 987/2009. The transitional period has been extended to " 2 years from the date when the central EESSI system will be developed, tested and delivered into production, ready for Member States to start the integration to the central system", and, for such purposes, the central EESSI system is considered delivered into production "when all the components of the central EESSI system have been developed, tested and agreed as fit for purpose by the European Commission following consultation with the Executive Board." See recitals 1 and 3 of Decision No E4 of 13 March 2014 concerning the transitional period as defined in Article 95 of Regulation (EC) No 987/2009 of the European Parliament and of the Council, OJ C 152, 20.5.2014, p. 21-23. See also Decision No E5 of 16 March 2017 concerning the practical arrangements for the transitional period for the data exchange via electronic means
} 


\section{Final remarks}

The public administration of the Single Digital Market is not merely a digital public administration, but rather a digital public administration capable of responding to the challenges of an interdependent socio-economic space such as that of the EU. Therefore, the public administration of the Single Digital Market corresponds to an eGovernment paradigm, anchored in the use of information and communication technologies (digital), operating beyond the borders of their own Member States (crossborder) and interconnected with the public administrations of the other Member States (interoperable), able to exhaust in a single contact the needs of interaction with individuals (citizens and businesses), without neglecting the standards of good administration revisited by the demands of the digital age (digital good administration). ${ }^{83}$

Even if the administrative authority of the EU is called to ensure the implementation of the Digital Single Market, that is, both the administrative authorities of the Member States and the institutions, bodies, offices and agencies of the EU, as co-dependent bodies $^{84}$ of the EU composite administrative structure ${ }^{85}$, the truth is that, as mentioned, the public administrations of the Member States will play a leading role as the "natural executives" 86 of EU policies and law.

The development of e-administration/eGovernment at Member State level is, therefore, a priority in the implementation of the Digital Single Market. The digital transformation of public administrations at Member State level not only facilitates the interaction of citizens and businesses with public administrations by avoiding unnecessary and time-consuming administrative procedures and facilitating the re-use of information previously made available for other purposes, but it also opens the way for closer cooperation between Member States' public administrations among themselves, thus perhaps, fostering the emergence of an integrated public administration within the EU.

But as the example of the coordination of social security systems demonstrates, in this ever-changing field, the range of opportunities equals the range of challenges. Ultimately, the full potential of eGovernment/e-administration can only be achieved if citizens and businesses are imbued with conditions of trust on the digital public services offered. Thus, one of the keys for success in the implementation of the Digital Single Market in the public sector lies not only in enhancing the exercise of rights through digital tools, but also in promoting trust and credibility in a public power exercised through these tools.

referred to in Article 4 of Regulation (EC) No 987/2009, OJ C 233, 19.7.2017, p. 3-5.

${ }^{83}$ Drawing attention to the necessary consideration of the digital solutions underpinning e-government in the light of the principles of proportionality, equality and non-discrimination, see Joana Covelo de Abreu, "Digital Single Market under EU political and constitutional calling: European electronic agenda's impact on interoperability solutions", UNIO - EU Law Journal 3(1) (2017), 135-139 [available at www.unio.cedu.direito.uminho.pt (last accessed 21.12.2017)].

${ }^{84}$ See Jürgen Schwarze, Droit Administratif Européen, 2a edição (Brussels: Bruylant, 2009), I-67.

${ }^{85}$ See Claudio Franchini, "Les notions d'administration indirecte et de coadministration", Droit Administratif Européen, dir. Jean-Bernard Auby and Jacqueline Dutheil de la Rochère (Brussels: Bruylant, 2007), 261.

${ }^{86}$ As opposed to the Commission as the "natural executive" of the EU - see J. Á. Fuentetaja Pastor, "El poder ejecutivo europeo", Revista de Derecho de la Unión Europea 18 (2010), 124 (free translation). 